\title{
Odpovědnost za újmu osobě poskytující pomoc veřejné moci (s důrazem na ozbrojené síly) ${ }^{1}$
}

\section{Liability for Damage to a Person Providing Assistance to Public Authorities (with an Emphasis on the Armed Forces)}

\author{
Ondřej Horák* ${ }^{*}$ Leopold Skoruša**
}

\begin{abstract}
Abstrakt
Prǐspèvek.je vènován problematice nábrady majetkové a nemajetkové úimy osobè, která poskytla součinnost veřejné moci (úredním osobám) a žláště pak ozbrojeným silám. Jedná se o specifický prúpad odpovédnosti státu, majici objektivni charakter (odpovédnost za výsledek). Zvlástni pozornost bude zamèrena na odškodňováni pozuistalých a na prechod náhrad na dédice. Půjde o pruni komplexni zpracování dané tematiky, která se vyznačuje radou interpretačnich problému z hlediska teorie (zvl. vątah veréjného a soukromébo práva) i praxe (naprr. zproštèni odpovédnosti státu č postaveni registrovaných partneru prì odškeodňováni pozuistalých). Cilem př̌spèvku bude kritická analýza současnébo stavu právni úpravy a predstavení návrbi de lege ferenda.
\end{abstract}

\section{Klíčová slova}

Újma; majetková újma; nemajetková újma; verégná moc; osoba poskytujici pomoc; odpovédnost; náhrada.

\begin{abstract}
The paper is devoted to the issue of compensation of property and non-material damage to a person who aided public authorities (persons in authority) and especially to the armed forces. This is a specific case of State liability, having an objective character (responsibility for result). Particular attention will be focused on compensation for survivors and on transfer of compensation in the event of injury to beirs. It will be the first comprehensive elaboration of the issue, which is characterized by a few interpretative problems in terms of theory (especially public and private law relations) and practice (e.g. absolution of state responsibility or status of registered partners in compensation of survivors). The aim of the paper will be a critical analyse for the current state of legal regulation and the proposal de lege ferenda.
\end{abstract}

* JUDr. Mgr. Ondřej Horák, Ph.D., Katedra dějin státu a práva, Právnická fakulta, Masarykova univerzita, Brno; Fakulta vojenského leadershipu, Univerzita obrany, Brno / Department of the History of the State and Law, Faculty of Law, Masaryk University, Brno, Czech Republic; Faculty of Military Leadership, University of Defence, Brno, Czech Republic / E-mail: onhorak@post.cz / ORCID: 0000-0003-3549-6539

** Mgr. Ing. Leopold Skoruša, Ph.D., Fakulta vojenského leadershipu, Univerzita obrany, Brno / Faculty of Military Leadership, University of Defence, Brno, Czech Republic / E-mail: leopold.skorusa@unob.cz / ORCID: 0000-0001-7688-0305

1 Článek vznikl v rámci řešení projektu specifického výzkumu MŠMT „Financování a ekonomické rízení prì zajišt'ování bezpečnosti a obrany“. 


\section{Keywords}

Damage; Property Damage; Non-Material Damage; Public Power; Person providing the Assistance; Responsibility; Compensation.

\section{Úvod}

Zajišt'ování vnitřní a vnější bezpečnosti státu je prováděno především veřejnými sbory a jejich přílušníky, plnění svěřených úkolů se však v některých situacích neobejde bez součinnosti veřejnosti. Způsob, jakým je pamatováno na zabezpečení osob, které při poskytování takové pomoci utrpěly újmu na majetku či zdraví, vypovídá o úrovni státu. Odpovědnost za újmu pomáhající osobě je upravena v osmnácti zákonech z období let 1985 až 2014, včetně zákona č. 219/1999 Sb., o ozbrojených silách ČR (dále také „OzbZ“'2) a zákona č. 222/1999 Sb., o zajišt’ování obrany ČR, přičemž zákonodárce zvolil různá legislativně-technická i normativní řešení.

V př́ipadě náhrady majetkové újmy (škody) má devět zákonů vlastní úpravu, čtyři odkazují na občanský zákoník, jeden na zákon o policii ČR, čtyři jsou bez odkazu.

$\mathrm{V}$ př́padě náhrady nemajetkové újmy (na zdraví nebo při usmrcení) odkazuje devět zákonů na zákoník práce, pět na občanský zákoník (z toho dva neprímo), zákon o ozbrojených silách na zákon o vojácích z povolání, tři jsou bez odkazu.

Smyslem úpravy bylo chránit (ve zvýšené míře ve srovnání se soukromou sférou) pomáhající osobu, resp. její pozůstalé. Vzhledem k modernizaci soukromého práva (přijetím občanského zákoníku v roce 2012) by však dnes mohlo být pro poškozeného výhodnější postupovat podle občanskoprávní úpravy.

Odpovědnosti za újmu pomáhající osobě sice byla věnována pozornost jak v komentářích $\mathrm{k}$ jednotlivým zákonům, tak $\mathrm{v}$ přehledových pracích, ovšem pouze výběrově. ${ }^{3}$ Teprve tento článek se snaží o komplexní zpracování tematiky, která se vyznačuje řadou interpretačních problémů z hlediska teorie i praxe. Př́spěvek vznikl v souvislosti s př́pravou komentáře k zákonu o ozbrojených silách Č́ ${ }^{4}$, což přimělo autory k zamyšlení nad povahou pomoci poskytnuté i dalším veřejným sborům.

2 Zkratka „OzbZ“ je zavedena analogicky ke zkratce „VojZ“, užívané (mj. také v ASPI) pro z. č. 221/1999 Sb., o vojácích z povolání. U z. č. 219/1999 Sb. se můžeme setkat také se zkratkou „ZOS“, která je však tradičně užívána pro z. č. 634/1992 Sb., o ochraně spotřebitele.

3 Srov. MATES, Pavel, Jindřich ŠKODA a František VAVERA. Veřejné sbory. Praha: Wolters Kluwer, 2011, s. 290 a násl.; KLÍMA, Karel a kol. Odpovédnost veréjné moci. Praha: Metropolitan University Prague Press, 2013, s. 431 a násl.; a KOPECKÝ, Martin. Civilní odpovědnost za výkon veřejné moci. In: HANDRLICA, Jakub (ed.). Verejné právo a právo soukromé: aktuálni tendence a výzvy verejnoprávni úpravy plynouci z.problematiky právního dualismu. Praha: E. Rozkotová, 2014, s. 135-144.

4 Vedoucím autorského kolektivu je L. Skoruša, vydavatelem Wolters Kluwer. Již dříve vyšel komentář k VojZ, na který částečně navazujeme. Srov. SKORUŠA, Leopold, Jaroslav DANĚK a kol. Zákon o vojácích zpovolání. Komentár. Praha: Wolters Kluwer, 2017, passim. 
Po představení základních pojmů se budeme nejprve věnovat rozboru majetkové újmy (věcné škody) a následně újmy nemajetkové (v př́ípadě újmy na zdraví nebo usmrcenî). $\mathrm{V}$ právních předpisech se většinou postupuje opačně (nejprve je řešena újma nemajetková a až následně majetková).

\section{Odpovědnost za újmu pomáhající osobě ve veřejnoprávních předpisech}

\subsection{Terminologie a systematika}

Většina zákonů upravuje odpovědnost za újmu způsobenou při činnosti veřejného sboru šířeji (nejen pomáhající osobě, ale také třetím osobám; výjimkou je např. zákon o požární ochraně). Zákon o ozbrojených silách řeší v \43 tři provázané situace odpovědnosti za škodu (způsobenou v souvislosti s plněním úkolů ozbrojených sil): pomáhající osobě ( 43 odst. 1 a 2), pomáhající osobou jinému (\$ 43 odst. 3), třetí osobě obecně (odst. 4). Logičtější by však bylo postupovat od obecného ke zvláštnímu, tedy nejprve upravit postavení třetích osob a až následně pomáhající osoby (jako je tomu např. v z. č. 273/2008 Sb., o Policii ČR, nebo z. č. 239/2000 Sb., o integrovaném záchranném systému a o změně některých zákonů).

Některé zákony včetně OzbZ zavedly legislativní zkratku „poškozeny" (srov. zákon o požární ochraně, zákon o obecní policii, zákon o Vězeňské službě a justiční stráži ČR, zákon o ochraně přírody a krajiny, lesní zákon či zákon o myslivosti), což je však problematické, protože také třetí osoba je v postavení poškozeného. Zákon o BIS užívá termín „pomáhajici osoba“, který považujeme za vhodnější, jinak většina úprav mluví o „poškozeném" (ovšem bez zavedení legislativní zkratky).

Právní předpisy většinou rozlišují osobní a věcnou pomoc (typicky zákon o požární ochraně, srov. \1 odst. 2 z. č. 133/1985 Sb.; výjimkou je zákon o státní službě, který mluví obecně o pomoci, srov. \125 z. č. 234/2014 Sb.). Nejprve a také podrobněji bývá řešena náhrada nemajetkové újmy a až následně náhrada majetkové újmy (výjimkou je zákon o obecní policii, srov. \12a a \24 z. č. 553/1991 Sb., a krizový zákon, srov. \36 z. č. 240/2000 Sb.). 


\subsection{Pomoc veřejné moci}

Pojem ,pomoc verejné moci (úredním osobám) “zahrnuje pomoc jak ozbrojeným silám a dalším součástem ministerstva obrany ${ }^{6}$, bezpečnostním sborům ${ }^{7}$ a jiným veřejným sborům ${ }^{8}$, tak dalším představitelům veřejné moci ${ }^{9} .^{10}$

Půjde o součinnost (pomoc) jak dobrovolnou (neformálnî), tak institucionalizovanou (formálnî), at' již nařízenou, nebo dohodnutou ${ }^{11}$. Oprávnění vyžadovat pomoc mají mj. velitelé zásahu, velitelé jednotky požární ochrany nebo obce (\$18 a \19 z. č. 133/1985 Sb., o požární ochraně), starosta obce či velitel zásahu (\$16 a \19 odst. 3 z. č. 239/2000 Sb., o integrovaném záchranném systému a o změně některých zákonů), strážník (『12a z. č. 553/1991 Sb., o obecní policii), policista (『 18 z. č. 273/2008 Sb., o Policii ČR), příslušník HZS (\$ 21 z.č. 320/2015 Sb. o hasičském záchranném sboru) či členové výjezdové skupiny (\ 18 odst. 2 z. č. 374/2011 Sb., o zdravotnické záchranné službě).

$\mathrm{V}$ př́ípadě zajišt'ování obrany je institucionalizovaná součinnost blíže upravena $\mathrm{v}$ části čtvrté z. č. 222/1999 Sb., přičemž zahrnuje poskytnutí věcných prostředků, pracovní povinnost a pracovní výpomoc (\13 až $\left.\int 28\right)$. Může být uložena přímo zákonem (u osob $\mathrm{v}$ pracovním či služebním poměru $\mathrm{k}$ veřejným institucím, viz \22), nebo na základě rozhodnutí (dodávacím př́kazem u věcných prostředků, viz $\ 13$ až $\ 20$, a povolávacím př́kazem k plnění pracovní povinnosti či pracovní výpomoci, viz \21 až \28).

5 Armádě ČR, Vojenské kanceláři prezidenta republiky a Hradní stráži (viz $\int 3$ odst. 2 OzbZ).

6 Viz $\int 6$ odst. 1, písm. a) až e) VojZ.

7 Policii ČR, Hasičskému záchrannému sboru ČR, Celní správě ČR, Vězeňské službě ČR, Generální inspekci bezpečnostních sborů, Bezpečnostní informační službě a Úřadu pro zahraniční styky a informace (viz \ 1 odst. 1 z. č. 361/2003 Sb.).

8 Např. Obecní policii.

9 V případě stráží (přírody, lesní, myslivecké a rybářské) byla tato odpovědnost zavedena novelou některých zákonů týkajících se veřejného činitele (z. č. 238/1999 Sb.), s účinností od 1. 1. 2000.

$10 \mathrm{~K}$ pojmu veřejných sborů srov. mj. MATES, Pavel, Jindřich ŠKODA a František VAVERA. Veřejné sbory. Praha: Wolters Kluwer, 2011, s. 1 a násl. Autoři nezařazují ozbrojené síly do veřejných sborů, protože „chráni zásadně vnèjši bezpečnost republiky“, zatímco „veřejné sbory puisobí zásadně dovnitř Ceské republiky". Toto kritérium však nepovažujeme za konstitutivní a také ozbrojené síly řadíme do veřejných sborů. Navíc ozbrojené síly plní kromě základního úkolu, kterým je obrana ČR proti vnějšímu napadení ( 9 OzbZ), také řadu dalších úkolů dovnitř státu (\14, 26 a 28 OzbZ).

11 Viz např. $\int 19$ z. č. 320/2015 Sb., o hasičském záchranném sboru. Podle důvodové zprávy má dohoda charakter veřejnoprávní smlouvy (důvodová zpráva je dostupná z: http://www.psp.cz/sqw/text/tiskt. sqw?O=7\&CT=459\&CT1=0), což je však sporné. Podle judikatury by takový charakter mít neměla (srov. usnesení zvláštního senátu ze dne 24. 6. 2009, sp. zn. Konf 24/2008-21), podle nejnovější literatury pouze $\mathrm{v}$ prrípadě, že by byla uzavřena mezi subjekty nadanými působností v oblasti veřejné správy (pak by se jednalo o veřejnoprávní smlouvu koordinační pečovatelské povahy). Blíže PŘÍKOPA, Vojtěch. Verejnoprávni smlouvy koordinační. Praha: C. H. Beck, 2018, s. 20 a násl. (Za připomínky děkujeme V. Př́kopovi). 


\subsection{Charakter odpovědnosti}

Problematika náhrady újmy je v obecné rovině upravena občanským zákoníkem (〔 2894 a násl.), v prrípadě škody při plnění úkolů veřejné moci se uplatní také zákon č. 82/1998 Sb., o odpovědnosti za škodu způsobenou při výkonu veřejné moci rozhodnutím nebo nesprávným úředním postupem (přičemž v jeho $\int 26$ je zakotvena subsidiarita občanského zákoníku). ${ }^{12}$ Předmětná subsidiarita je též potvrzena judikaturou Ústavního soudu, ze které plyne nezbytnost zvláštní veřejnoprávní regulace náhrady škody způsobené orgánem veřejné moci, kdy automatická použitelnost právní úpravy odpovědnosti za škodu, vyjádřené v občanském zákoníku jakožto základním kodexu upravujícím soukromoprávní vztahy, je vyloučena. ${ }^{13}$

Odpovědnost za újmu osobě, která poskytla veřejné moci (úředním osobám) součinnost, stojí na pomezí odpovědnosti vưči „vlastním“ (osobám ve služebním poměru) a vưči „cizím“ (třetím osobám). Jedná se o specifický případ odpovědnosti státu ve veřejné sféře, jde o objektivní odpovědnost (za výsledek). Zproštění odpovědnosti státu (liberace) je v př́padě majetkové i nemajetkové újmy možné pouze $\mathrm{v}$ prrípadě, že si újmu poškozený způsobil zaviněně (resp. úmyslně). Většina zákonů požaduje úmysl, pouze krizový zákon a zákon o zdravotnické záchranné službě mluví šíreji o zavinění (tedy i nedbalosti), zákon o integrovaném záchranném systému o situaci, že si poškozený ,zpนisobil škkodu sám "(což podle našeho názoru odpovídá zaviněnî), a zákony o požární ochraně a rybářské stráži nezmiňují žádný důvod liberace (domníváme se však, že i v těchto případech je možná liberace, pokud si škodu poškozený způsobil úmyslně; argumentace analogií a principy).

Subsidiárně je možné použít občanský zákoník - na rozdíl od OzbZ (\$ 43 odst. 6) to sice není ve většině předpisů uvedeno výslovně, ale vyplývá to z literatury i judikatury, zdůrazňující princip jednoty a bezrozpornosti právního řádu a chápající vztah soukromého a veřejného práva jako „obecného“ a ,zvláštního“. ${ }^{14}$

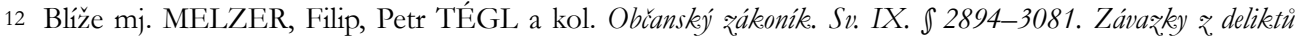
a zjiných právních divvodiu. Praha: Leges, 2018; MATES, Pavel a Jakub SEVERA. Odpovédnost státu za výkon veřjné moci. Praha: Leges, 2014; a SIMON, Pavel. Odpovédnost za škodu př výkonu verejné moci. Praha: C. H. Beck, 2019.

13 Blîže Nález Ústavního soudu ČR - K odpovědnosti státu za škodu a rovnosti účastníků řízení. In: Ústavní soud ČR, 2010, roč. 2010, II. ÚS 1612/09-1.

14 Srov. mj. Správni právo, 2011, roč. 44, č. 1-2 (příspěvky z odborného semináře „Prolínáni verejného a soukromébo práva "); HANDRLICA, Jakub (ed.). Verejné právo a právo soukromé: aktuální tendence a výzvy verejnoprávní úpravy plynoucí z problematiky právního dualismu. Praha: UK, 2014; GERLOCH, Aleš a Katarzyna ŽÁK KRZYŽANKOVÁ (eds.). Soukromé a verejné v kontextu institucionálních a normativních promèn práva. Plzeň: A. Čeněk, 2017; z oblasti služebního práva SKORUŠA, Leopold, Ondřej HORÁK, Radim VIČAR a Tomáš ZBOŘIL. Zákon o vojácích z povolání v systému českého práva (k problematice výkladu některých pojmů). Vojenské rozhledy, Brno: Univerzita obrany, 2017, roč. 26, č. 2, s. 33-43. 
Náhradu škody poskytuje v zastoupení státu většinou prŕislušný ústřední orgán státní správy (v prípadě pomoci ozbrojeným silám Ministerstvo obrany, viz $\int 43$ odst. 5 OzbZ). Jedná se o občanskoprávní vztah (『7 odst. 1 OSŘ), o právu na náhradu škody rozhodují soudy v občanském soudním ř́zení. ${ }^{15}$

\subsection{Náhrada (věcné) škody}

Náhradu majetkové újmy neboli škody (terminologie OZ), resp. náhradu škody na věcech (terminologie starého OZ a speciálních úprav) řeší platné zákony většinou přímo (devět z osmnácti), pouze čtyři odkazují na občanský zákoník, jeden na zákon o Policii ČR a čtyři jsou zcela bez odkazu.

1. Vlastni úprava: při pomoci policii (\$ 24 odst. 3 z. č. 553/1991 Sb., o obecní policii, a \ 95 odst. 5 z. č. 273/2008 Sb., o Policii ČR), Vězeňské službě (\ 23 odst. 3 z. č. 555/1992 Sb., o Vězeňské službě a justiční stráži ČR), strážím přírody, lesní a myslivecké (\$ 81b odst. 3 z.č. 114/1992 Sb., o ochraně přírody a krajiny, \39a odst. 3 z. č. 289/1995 Sb., lesní zákon, \16 odst. 1 z. č. 449/2001 Sb., o myslivosti), při uloženém poskytnutí věcných prostředků při zajišt'ování obrany státu ( 59 z. č. 222/1999 Sb., o zajišst'ování obrany ČR), zaměstnancům finanční správy ( 17 odst. 3 z. č. 456/2011 Sb., o Finanční správě České republiky) a Celní správě (\ 51 odst. 3 z. č. 17/2012 Sb., o Celní správě ČR) se sice uplatní vlastní úprava, která však vychází z občanskoprávních předpisů. Hradí se skutečná škoda, a to zásadně uvedením v předešlý stav; není-li to možné nebo účelné, hradí se v penězích. Poškozené pomáhající osobě může být přiznána i úhrada nákladů spojených s pořízením nové věci náhradou za věc poškozenou. Subsidiárně je možné použít občanský zákoník.

2. Úprava sodkazem:

a) na občanský zákonik: při pomoci jednotkám požární ochrany (\84 odst. 5 z. č. 133/1985 Sb., o požární ochraně; v textu je uvedeno „náhrada škody fyzické osobě ... se poskytuje podle občanskébo zákoniku“), ozbrojeným silám (『 43 odst. 6 z. č. 219/1999 Sb., o ozbrojených silách ČR; v textu „ř́dí se ... zulástním právní predpisem“, v pozn. pod čarou „zákon ř. 40/1964 Sb., občanský zákoník, ve znèni poz-

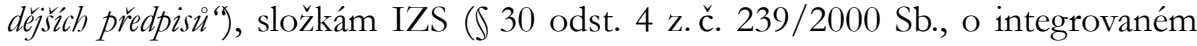
záchranném systému; v novelizovaném textu ,podle ustanoveni občanského zákoníku $v$ doběv vniku škody "16) a rybářské stráži, a \18 odst. 6 z. č. 99/2004 Sb., o rybářství;

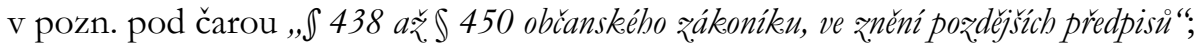

15 Z judikatury srov. 1) usnesení Nejvyššího správního soudu ze dne 11. 5. 2005, č. j. Na 12/2005-8, č. 671/2005 Sb. NSS, s právní větou: „O nároku na nábradu škody zprisobené prí výkonu veřjné moci rozhodnutím nebo nesprávným úredním postupem podle zákona č. 82/1998 Sb., o odpovédnosti za škodu zpiosobenou pri výkonu verejné moci roz̧odnutím nebo nesprávným úredním postupem, rozhoduji soudy v občanském soudnim rízení."

2) rozsudek Nejvyššího soudu ze dne 17. 6. 2009, sp. zn. 25 Cdo 1649/2007, s právní větou: „Za škodu vZnikelou v prícinné souvislosti s krizovým opatrením odpovidá stát, nikoli orgán krizového ř́zení. Ve sporu o nábradu této škody vystupuje za stát v občanském soudním ř́zeni ministerstvo vnitra."

$16 \mathrm{~V}$ původním znění „podle zulástnich právnich predpisů v době vąniku škody“. 
b) na zákon o Policii: při pomoci př́islušníkům GIBS (〔 55 z. č. zákon č. 341/2011 Sb., o Generální inspekci bezpečnostních sborů a o změně souvisejících zákonů; v textu „se pouřijí obdobně \95 a \96 zákona o Policii Ceské republiky “).

3. Úprava bez odkazu: při pomoci BIS (\ 17 odst. 2 z. č. 154/1994 Sb., o Bezpečnostní informační službě), při uloženém poskytnutí věcných prostředků v krizových situacích (\36 odst. 2 z. č. 240/2000 Sb., o krizovém řízení a o změně některých zákonů; v textu ,podle právnich predpisu platných v době vzniku škody “17), výjezdové skupině (\ 18 odst. 4 z. č. 374/2011 Sb., o zdravotnické záchranné službě) a státnímu zaměstnanci ( 125 z.č. 234/2014 Sb., o státní službě) se bude postupovat také podle občanského zákoníku (subsidiarita OZ, analogie s ostatními předpisy).

\subsection{Náhrada při újmě na zdraví nebo při usmrcení}

Náhrady při ublížení na zdraví a při usmrcení (terminologie OZ), resp. došlo-li k újmě na zdraví nebo smrti (terminologie většiny speciálních úprav) neřeší platné zákony samostatně, ale většinou odkazují na zvláštní úpravu (patnáct z osmnácti, tři nemají žádný odkaz).

1. Úprava s odkazem:

a) na zákoník práce $e^{18}$ při pomoci jednotce požární ochrany (\80 a \81 z. č. 133/1985 Sb., o požární ochraně), Vězeňské službě (\$ 23 odst. 2 z. č. 555/1992 Sb., o Vězeňské službě a justiční stráži ČR), strážím přírody, lesní, myslivecké a rybářské (\81b odst. 2 z.č. 114/1992 Sb., o ochraně přrirody a krajiny, \39a odst. 2 z. č. 289/1995 Sb., lesní zákon, \ 16 odst. 1 z. č. 449/2001 Sb., o myslivosti, a \ 18 odst. 6 z. č. 99/2004 Sb., o rybářství), při uložené pracovní povinnosti či pracovní výpomoci při zajišstování životně důležitých funkcí státu (\ 60 odst. 2 z. č. 222/1999 Sb., o zajišt'ování obrany ČR), složkám integrovaného záchranného systému (\$ 30 odst. 3 z. č. 239/2000 Sb., o integrovaném záchranném systému a o změně některých zákonů) a orgánům krizového řízení (\36 odst. 3 z. č. 240/2000 Sb., o krizovém řízení a o změně některých zákonů); ${ }^{19}$

b) na občanský zákoník:

- prímo: při pomoci policii (\24 odst. 4 z. č. 553/1991 Sb., o obecní policii ${ }^{20}$, a \ 95 odst. 4 z. č. 273/2008 Sb., o Policii ČR) a Celní správě (\51 odst. 2 z. č. 17/2012 Sb. o Celní správě ČR);

- neprímo: při pomoci příslušníkům GIBS (『 55 z.č. zákon č. 341/2011 Sb., o Generální inspekci bezpečnostních sborů, odkazující na z. č. 273/2008 Sb., o Policii ČR, a ten na občanský zákoník) a zaměstnancům finanční správy

17 Původně však byl v pozn. pod čarou odkaz na občanský zákoník.

18 Konkrétně se mluví o poskytnutí náhrady „podle predpisů o odškodňování pracounich úrazĩ“.

19 Blíže PETR, Bohuslav a kol. Zákon o myslivosti. Komentár. Praha: Wolters Kluwer, 2015, s. 62-65.

$20 \mathrm{~V}$ původním znění bylo „podle predpisůo odškodňovánípracovních úrazuip pracovníkư"; změněno z. č. 274/2008 Sb., kterým se mění některé zákony v souvislosti s přijetím zákona o Policii České republiky. 
(『 17 odst. 2 z. č. 456/2011 Sb. o Finanční správě České republiky, odkazující na zákon o státní službě); ${ }^{21}$

c) na zákon o vojácích zpovolání

- prímo: prri pomoci ozbrojeným silám, Vojenské policii, Vojenskému zpravodajství (\ 43 odst. 2 z. č. 219/1999 Sb., o ozbrojených silách ČR);

- neprímo: při uložené pracovní povinnosti či pracovní výpomoci ve prospěch ozbrojených sil (\ 61 odst. 2 z. č. 222/1999 Sb., o zajišt'ování obrany ČR $)^{22}$.

2. Úprava bez. odkazu: při pomoci BIS (\ 17 odst. 1 z. č. 154/1994 Sb., o Bezpečnostní informační službě), výjezdové skupině (『 18 odst. 4 z. č. 374/2011 Sb., o zdravotnické záchranné službě) a státnímu zaměstnanci (\$ 125 z. č. 234/2014 Sb., o státní službě) se bude postupovat podle OZ (není stanoveno výslovně, ale je to dovozováno literaturou). ${ }^{23}$

Podle zákona o Vězeňské službě a justiční stráži má vláda stanovit nařízením, ve kterých př́padech a v jakém rozsahu: a) nále ží poškozenému jednorázové mimořádné odškodnění, b) se zyyšuje jednorázové odškodnění náležející podle pracovněprávních předpisů pozůstalým; podle zákona o obecní policii a zákona o Policii ČR lze „v př̆padech hodných zuláštního zretele "poskytnout jednorázové mimořádné odškodnění (ve srovnání s původním zněním zákona o obecní policii a s předchozím zákonem o Policii ČR z roku 1991 byla vypuštěna zmocnění $\mathrm{k}$ úpravě vládním nařízením). ${ }^{24}$

Dosud sice nebyl k poskytnutí jednorázového mimořádného odškodnění podle výše uvedených zákonů vydán prováděcí předpis, mohlo by se však postupovat analogicky podle nařízení vlády týkajícího se požární ochrany (jazykový výklad ${ }^{25}$ nebo podle zákona o služebním poměru příslušníků bezpečnostních sborů (systematický výklad) ${ }^{26}$.

21 Blíže VANGELI, Benedikt. Zákon o Policii Ceské republiky. Komentár. 2. vyd. Praha: C. H. Beck, 2014, s. 369-374, zvl. s. 373; a ŠTEINBACH, Miroslav, René ŠLESINGER, Miroslav ZIMMERMANN, Milan BÍLEK a Kateřina HLAVÁČOVÁ. Zákon o Policii Ceské republiky. Komentár. Praha: Wolters Kluwer, 2019; VETEŠNÍK, Pavel a Luboš JEMELKA. Zákon o obecní policii. Komentár. 2. vyd. Praha: C. H. Beck, 2019, s. 334-342.

$22 \mathrm{~V}$ textu je uvedeno, že se poškození odškodňují „za stejných podmínek jako u vojáke̊ v mimořádné službě", v pozn. pod čarou je odkaz na starý branný zákon (\$ 47 z. č. 218/1999 Sb., o rozsahu branné povinnosti a o vojenských správních úřadech), v současném branném zákoně by šlo o \ 15 a 16 z. č. 585/2004 Sb., o branné povinnosti a jejím zajišt'ování. Postupuje se podle VojZ.

23 Bliže CHROBÁK, Jiři a Ladislav POKORNÝ. Zákon o Bezpečnostni informačni službè. Komentár. Praha: Wolters Kluwer, 2016, s. 91-92; BĚLINA, Miroslav. In: PICHRT, Jan a kol. Zákon o státni službě. Komentár. Praha: Wolters Kluwer, 2015, s. 405-406.

24 Srov. nař. vl. č. 174/1993 Sb., o jednorázovém mimořádném odškodnění za poškození zdraví nebo smrt v souvislosti s pomocí poskytnutou Policii České republiky nebo obecní policii.

25 Srov. nař. vl. č. 34/1986 Sb., o jednorázovém mimořádném odškodnění osob za poškození na zdraví při plnění úkolů požární ochrany, ve znění pozdějších předpisů.

26 Srov. \105 (jednorázové odškodněnî) a \109 (jednorázové odškodnění pozůstalých) z. č. 361/2003 Sb. 


\section{Náhrada újmy podle občanského zákoníku, zákoníku práce a služebních zákonů}

V rámci této kapitoly bylo zvoleno tematické seřazení podkapitol (od obecného ke zvláštnímu, od pravidla k výjimkám). Nejprve se budeme věnovat občanskému zákoníku jako stěžejnímu obecnému předpisu, dále zákoníku práce, podle kterého se bude postupovat při poskytování náhrady za újmu na zdraví nejčastěji, a až následně služebním zákonům. ${ }^{27}$

\subsection{Náhrada újmy podle občanského zákoníku}

Občanský zákoník představuje východisko a obecný předpis problematiky náhrady újmy (\ 2894 a násl.), který se bude užívat subsidiárně (pokud jiný předpis nestanoví jinak). Využití najde zejména u meziodvětvových institutů, např. promlčení, úroků z prodlení2 ${ }^{28}$ či tzv. regresu ${ }^{29}$.

OZ rozlišuje náhradu majetkové újmy (neboli škodu) a náhradu nemajetkové újmy, zejména náhrady při újmě na přirozených právech člověka, upravenou v \2956 až \ 2968 (13 ustanovenî). Majetková újma se nahrazuje v zásadě vždy, nemajetková pouze pokud je výslovně ujednána nebo to zvlášt' stanoví zákon (『 2894 odst. 2).

Škoda se nahrazuje především uvedením věci do předešlého stavu (zejména opravou); pokud to není dobře možné nebo to žádá poškozený, hradí se škoda v penězích ( $\int 2951$ odst. 1); dále se také poskytuje náhrada vedlejších výdajů (nezbytných k pořízení nové věci nebo opravy poškozené věci).

Nemajetková újma se odčiňuje přriměřeným zadostiučiněním, které musí být poskytnuto v penězích, pokud jiný způsob zadostiučinění nezajistí skutečné a dostatečně účinné odčinění způsobené újmy (『 2951 odst. 2). Hradí se skutečná škoda a ušlý zisk (\$ 2952). Pokud nelze výši náhrady škody přesně určit, stanoví ji podle spravedlivého uvážení jednotlivých okolností prrípadu soud (\$2955). Soud má tzv. moderační právo - z důvodů zvláštního zřetele hodných může výši náhrady škody snížit (\$ 2953).

27 Srov. mj. ŘEHOŘOVÁ, Lucie. Náhrada nemajetkové újmy např́řc služebními vztahy. In: PICHRT, Jan, Martin KOPECKÝ a Jakub MORÁVEK (eds.). Služebni vz̨taby a výkon závislépráce. Praha: Wolters Kluwer, 2016, s. 145-157.

28 Srov. rozsudek Nejvyššího správního soudu ze dne 31. 8. 2016, č. j. 2 As 139/2016-22, č. 3526/2017 Sb.

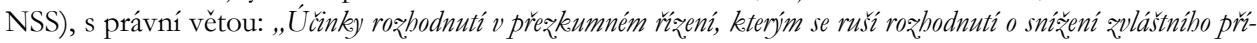

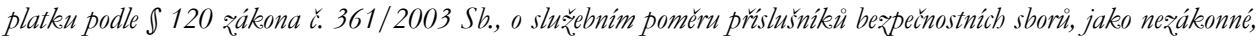

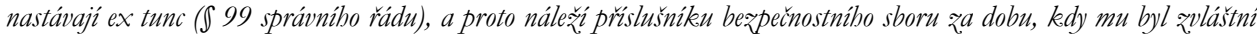

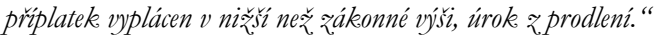

29 Srov. rozsudek Nejvyšš́iho soudu ze dne 14. 5. 2018, sp. zn. 25 Cdo 5551/2017, s právní větou: „Jestliže

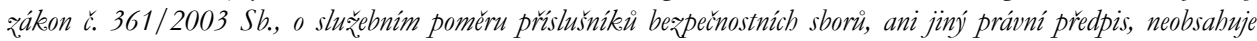

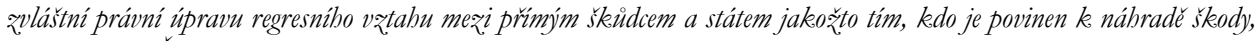
mữ̌e se stát (Česká republika prostrédnictvím př̌slušnébo beapečnostníbo sboru) domáhat postibu vǐci takovému škuidci za pouřití obecné úpravy regresu podle \2917 o. ₹:" 
Při ublížení na zdraví nebo při usmrcení upravuje OZ v zásadě deset druhů náhrad (sedm obecných a tři speciálně při usmrcení nebo zvlášt' závažném ublížení na zdraví): 1) náhradu za bolest (\2958); 2) náhradu za ztížení společenského uplatnění (\$2958); 3) náhradu nemajetkové újmy osob blízkých (\$2959); 4) náhradu (účelně vynaložených) nákladů spojených s péčí o zdraví (\$ 2960); 5) náhradu (přiměřených) nákladů pohřbu (\2961); 6) náhradu za ztrátu na výdělku po dobu pracovní neschopnosti (\$ 2962); 7) náhradu za ztrátu na výdělku po skončení pracovní neschopnosti (\$ 2963); 8) náhradu za ztrátu na důchodu (\2964); 9) náhradu za bezplatně poskytované práce (\$ 2965); 10) náhradu nákladů na výživu pozůstalým (\$2966).

Občanský zákoník opustil dosud panující pojetí, že by měl existovat sazebník výše náhrad stanovený v podzákonném předpisu (náhradovou vyhláškovou) a naopak dává soudcům volnou ruku ke stanovení náhrady újmy při zohlednění okolností jednotlivých prrípadů. Ke sjednocení soudního rozhodování připravil Nejvyšší soud nezávaznou Metodiku ke nábradě nemajetkové újmy na zdraví, která blíže upravuje způsob výpočtu náhrad bolestného a ztížení společenského uplatnění. U bolestného v zásadě pokračuje náhrada formou bodování újmy (1 bod bolestného je stanoven jako 1 \% průměrné hrubé měsíční nominální mzdy v národním hospodářství za kalendářní rok předcházejícího roku, v němž vznikl nárok (v roce 2019 to je 318,85 Kč). U ztížení společenského uplatnění byla zavedena nová koncepce, zohledňující ztrátu funkčních schopností jednotlivce, a to formou procentního vyjádření ztráty životních př́ležitostí v devíti oblastech (je možno prriznat až čtyřistanásobek průměrné hrubé měsíční nominální mzdy v národním hospodářství za kalendářní rok předcházející roku, v němž se ustálil zdravotní stav postiženého (v roce 2019 to je 12754000 Kč).

Výše ostatních náhrad nemajetkové újmy v Metodice řešena není. Při určení výše náhrady za duševní útrapy spojené s usmrcením osoby blízké (\$ 2959) by se podle judikatury (zvl. srov. zásadní rozsudek NS ze dne 19. 9. 2018, sp. zn. 25 Cdo 894/2018, navazující na nález ÚS ze dne 22. 12. 2015, sp. zn. I. ÚS 2844/14) měly zohlednit okolnosti jak na straně pozůstalého (zejména intenzita vztahu se zemřelým, věk zemřelého a pozůstalého, existenční závislost na zemřelém, další satisfakce, př́padně také okolnosti nehody jako např. osobní přítomnost při nehodě), tak na straně škůdce (zejména postoj ke škodní události, dopad události do jeho duševní sféry, forma a míra zavinění a v omezeném rozsahu i majetkové poměry škůdce).

Podle rozsudku NS z 12. 4. 2016 (sp. zn. 4 Tdo 1402/2015) se mělo stanovení výše náhrady nemajetkové újmy odvíjet v základním rozpětí 240000 Kč až 500000 Kč pro skupinu citově nejblíže spjatých osob (manžel, děti, rodiče), za každou mimořádnou okolnost (např. ztrátu jediného blízkého př́ibuzného nebo osobní přítomnost 
při nehodě) ještě k navýšení o 100000 Kč. ${ }^{30}$ Ve výše uvedeném rozsudku NS (sp. zn. 25 Cdo 894/2018) se zpřesňuje, že „za základni částku nábrady, modifikovatelnou s užitím qákonných a judikaturou dovozených hledisek, lze považovat v prípadě nejbližšich osob (manžel, rodiče, děti) dvacetinásobek prümèrné hrubé mèsični nominálni mzdy na prépočtené počty zamèstnancư v národnim hospodárstvi za rok predcházejici smrti poškozeného", přičemž judikatura NS je hodnocena již jako ustálená (srov. usnesení ÚS sp. zn. II. ÚS 2997/19).

\subsection{Náhrada újmy na zdraví podle zákoníku práce}

K předpisům pro odškodňování pracovních úrazů náleží zákoník práce (z. č. 262/2006 Sb., dále také „ZP“) a nařízení vlády o odškodňování bolesti a ztížení společenského uplatnění způsobené pracovním úrazem nebo nemocí z povolání (č. 276/2015 Sb.). Pracovní úrazy a jejich odškodňování jsou upraveny v \269 až \275 ZP (25 ustanovenî).

ZP upravuje osm druhů náhrad újmy na zdraví (pět obecných a tři při úmrtî): 1) za ztrátu na výdělku po dobu pracovní neschopnosti (\$ 271a); 2) za ztrátu na výdělku po skončení pracovní neschopnosti ( $(271 b) ; 3$ a 4) za bolest a za ztížení společenského uplatnění (\$ 271c); 5) za účelně vynaložené náklady spojené s léčením (\$ 271d); 6) za přiměřené náklady spojené s pohřbem (\$ 271g); 7) nákladů na výživu pozůstalých (\$271h); 8) jednorázové odškodnění pozůstalých (\$ 271i). Ve srovnání se služebními zákony může soud výši odškodnění podle \271c a \271i přiměřeně zvýšit (\$ 271s). ${ }^{31}$

\subsection{Náhrada újmy na zdraví podle zákona o vojácích z povolání}

$\mathrm{K}$ předpisům pro odškodňování služebních úrazů náleží zákon o vojácích z povolání (z.č. 221/1999 Sb., dále také „VojZ“) a vyhláška Ministerstva obrany o postupu při určování výše náhrady za bolest a za ztížení společenského uplatnění vojáků (č. 346/2015 Sb.). Služební úrazy a jejich odškodňování jsou upraveny v \116 až \ 125 VojZ (10 ustanovení).

VojZ upravuje deset druhů náhrad újmy na zdraví (šest obecných a čtyři při úmrtî): 1) za ztrátu na služebním platu po dobu neschopnosti výkonu služby ( $(117) ; 2)$ za ztrátu na služebním platu po skončení neschopnosti výkonu služby (\$ 118); 3-5) za bolest, za ztížení společenského uplatnění, za účelně vynaložené náklady spojené s léčením (\$ 119); 6) jednorázové mimořádné odškodnění (\$ 120); 7) za (účelně vynaložené) náklady spojené s pohřbem (\122); 8) nákladů na výživu pozůstalých (\$123); 9) jednorázové odškodnění pozůstalých $(\$ 124) ; 10)$ jednorázové mimořádné odškodnění pozůstalých

30 Blíže BEZOUŠKA, Petr. In: HULMÁK, Milan a kol. Občanský zákoník. VI. Závazkové právo. Zulástni cást (』 2055-3014). Praha: C. H. Beck, 2014, zvl. s. 1703-1723; a DOLEŽAL, Tomáš a Filip MELZER. In: MELZER, Filip, Petr TÉGL a kol. Občanský zákonik. Sv. IX. \ 2894-3081. Závazky z deliktů a zjiných právnich dìvodì. Praha: Leges, 2018, zvl. s. 988-1034.

31 Blíže NOVOTNÝ, Zdeněk. In: PICHRT, Jan a kol. Zákoník práce. Zákon o kolektivním vyjednávání. Praha: Wolters Kluwer, 2017, s. 746-801. 
(〔 125). Ve srovnání se ZP obsahuje VojZ ještě jednorázové mimořádné odškodnění a jednorázové mimořádné odškodnění pozůstalých. ${ }^{32}$

\subsection{Náhrada újmy na zdraví podle zákona o služebním poměru příslušníků bezpečnostních sborů}

K předpisům pro odškodňování služebních úrazů náleží zákon o služebním poměru př́slušníků bezpečnostních sborů (z. č. 361/2003 Sb., dále také „ZSP“) a vyhláška Ministerstva vnitra o postupu při určování výše náhrady za bolest a za ztížení společenského uplatnění př́ílušníků bezpečnostních sborů (č. 277/2015 Sb.). Služební úrazy a jejich odškodňování jsou upraveny v \100 až 110 ZSP (10 ustanovení).

ZSP upravuje devět druhů náhrad újmy na zdraví (šest obecných a tři při úmrtî): 1) za ztrátu na služebním přijmu po dobu neschopnosti ke službě (\$102); 2) za ztrátu na služebním př́ijmu po skončení neschopnosti ke službě ( $(103) ; 3$ a 4) za bolest a za ztížení společenského uplatnění (\$ 104); 5) za účelně vynaložené náklady spojené s léčením ( ( 107); 6) jednorázové odškodnění (\$ 105); 7) za přiměřené náklady spojené s pohřbem (\107); 8) nákladů na výživu pozůstalých (\$ 108); 9) jednorázové odškodnění pozůstalých (\ 109). Ve srovnání se ZP obsahuje ZSP ještě jednorázové odškodnění, ve srovnání s VojZ však nemá jednorázové mimořádné odškodnění pozůstalých. ${ }^{33}$

\subsection{Odškodnění pozůstalých}

V rámci problematiky odškodňování pozůstalých se můžeme setkat se dvěma interpretačními problémy, významnými z hlediska teorie (provázanost veřejného a soukromého práva, zohlednění evropského antidiskriminačního práva včetně judikatury) i praxe (finančně i ideově). Půjde o výklad pojmu „domácnost“ a „manžell“ a zejména o řešení otázky, zda odškodnění pozůstalým podle služebních zákonů náleží také registrovanému partnerovi. ${ }^{34}$

Domácnost / společná domácnost. Tyto pojmy vymezuje v návaznosti na OZ/64 pouze ZSP (\ 201 odst. 3); ZPr, VojZ a kupodivu ani nový ObčZ tak nečiní, stále však můžeme vycházet z (již neplatné) úpravy v \115 OZ/64 (,domácnost tvoř fyzické osoby, keteré spolu trvale řiji a společné ubrazuji náklady na své potreby "), včetně judikatury.

Společná domácnost bývá charakterizována jako „spotrebni společenstvi trvalé povaby “; trvalost je dána $\mathrm{v}$ př́padě objektivně zjistitelných okolností, které „svědči o úmyslu vést takové

32 Blíže SKORUŠA, Leopold, Jaroslav DANĚK a kol. Zákon o vojácích zpovolání. Komentár. Praha: Wolters Kluwer, 2017, s. 288-303.

33 Bliže TOMEK, Petr. Zákon o slư̌ęním pomèru prǐslušnikủ berpečnostních sborì. S komentárem k. 1. 1. 2019. 3 aktualiz. vyd. Olomouc: ANAG, 2019; a CHROBÁK, Jiří a kol. Zákon o slǔ̌ęnim pomèru př̌slušnikì bezpečnostnich sborü. Praha: Wolters Kluwer, 2019.

$34 \mathrm{~V}$ této podkapitole navazujeme na HORÁK, Ondřej. Přechod práv jinak než děděním z pracovního a služebních poměrů. Práuni roz̧bledy, Praha: C. H. Beck, 2016, roč. 24, č. 20, s. 713-717. 
společenství trvale, nikeliv jen na préchodnou dobu“ (sp. zn. 17 Co 189/1978 ${ }^{35}$ ); trvalost soužití nezaniká, pokud se některá z osob ze společné domácnosti po přechodnou dobu nachází na jiném místě (např. z důvodu pracovní cesty či studia). Soudní praxe dospěla také k závěru, že nikdo nemůže být současně členem dvou nebo více společných domácností (21 Cdo 678/201136).

Manžel/partner. Ve služebním právu je sice výslovně zakotven zákaz diskriminace (\2 VojZ, \16 odst. 4 a \ 77 ZSP), VojZ ani ZSP však neřeší problematiku registrovaného partnerství, jehož uzákonění (z.č. 115/2006 Sb.) bylo záhy zohledněno v ZP (z. č. 362/2007 Sb.) i jiných právních předpisech. V novém OZ platí (vyjma rodinného práva) ustanovení o manželství a o právech a povinnostech manželů obdobně pro registrované partnerství a práva a povinnosti partnerů (\$ 3020).

V resortní praxi je zastáván doslovný výklad pojmu ,manžel"odpovídající původním záměrům předkladatelů. Při aplikaci však nelze pustit ze zřetele také evropský a lidskoprávní rozměr problematiky. Z unijního práva půjde zejména o směrnici Rady 2000/78/ES, kterou se stanoví obecný rámec pro rovné zacházení v zaměstnání a povolání (z judikatury srov. zvl. C-267/06, Tadao Maruko proti Versorgungsanstalt der deutschen Bühnen, dále C-147/08, Jürgen Römer proti Freie und Hansestadt Hamburg, a spojené věci C-124/11, C-125/11 a C-143/11, Bundesrepublik Deutschland proti Karen Dittrich a Robert Klinke a Jörg-Detlef Müller proti Bundesrepublik Deutschland). ${ }^{37}$ Předně je však nutné zvážit, zda a jaká plnění podle služebních zákonů spadají do oblasti a rozsahu působnosti směrnice, a jaké je postavení manželství a registrovaného partnerství v rámci vnitrostátní úpravy. ${ }^{38}$

35 Srov. rozsudek Krajského soudu v Brně ze dne 19. 7. 1978, sp. zn. 17 Co 189/1978, s právní větou:

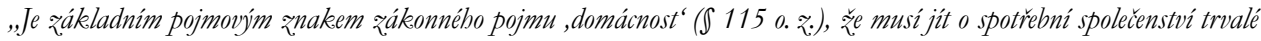
povahy. O spotřbni společenstvi jde tehdy, jestliže určité osoby hospodař společně se svými prǐjmy, pričemž se nevyžaduje, aby tyto osoby byly v príbuzenském nebo jiném obdobném vątahu. Trvalost tohoto vątahu je dána tehdy, jestliže tu jsou objektivnè zjïstitelné okolnosti, které svédči o úmyslu vést takové společenstvi trvale, nikoliv jen na préchodnou dobu. "

36 Srov. rozsudek Nejvyššího soudu ze dne 10. 10. 2012, sp. zn. 21 Cdo 678/2011. Právní věta: „Povaha společné domácnosti jakožto skutečného (faktickébo) a trvalébo spotřebního společenstvi dvou nebo více fyzickejch osob zppravidla vylučuje, aby společnou domácnost tvorily fyzické osoby, keteré spolu nechtěji být členy tébož spotrebního společenství, a aby stejná fyżická osoba byla současnè členem dvou nebo více spolećných domácností."

37 Dostupné z: http://curia.europa.eu/jcms/jcms/j_6/cs/ [cit. 15.8.2019].

38 Srov. rozsudek Soudního dvora (velkého senátu) ze dne 1. 4. 2008, Tadao Maruko proti Versorgungsanstalt der deutschen Bühnen, s právní větou: „Clánek 1 ve spojeni s čl. 2 odst. 2 pism. a) smèrnice 2000/78 bráni takové právni úpravě, jaká je predmètem pưvodníbo ř́zení, podle které pozuistalému registrovanému partnerovi neni po smrti jeho partnera vyplácena pozuistalostni dávka odpovidajici pozuistalostni dávce poskytované pozuistalému manželovi, ačkoli ve vnitrostátním právu registrované partnerstvi stavi osoby téhožpoblaví, pokud jde o pozuistalostni dávku, keterá je prédmètem pưvodního ř́zení, do situace srovnatelné se situaci manželì. Je na prédkládajicím soudu, aby ovèril, qda je pozuistalý partner v situaci srovnatelné se situaci manžela, který pobirá pozůstalostni dávku stanovenou systémem oborovébo zaopatreni, který spravuje Versorgungsanstalt der deutschen Bühnen. "Dostupné z: http://curia.europa.eu/juris/liste. jsf ?language $=$ cs\&num $=C-267 / 06$ [cit. 15. 8.2019]. 
Domníváme se, že z judikatury Soudního dvora EU vyplývá, že náhrady pozůstalým při úmrtí vojáka či př́slušníka 1) nespadají pod výluku podle čl. 3 odst. 3 směrnice $^{39}$, a 2) mohou být považovány za případ „odméňováni" ve smyslu čl. 3 odst. 1 písm. c) směrnice, resp. mohou být kvalifikovány jako „odmèna“ve smyslu čl. 141 Smlouvy ES. Dále je zřejmé, že vnitrostátní (pracovněprávnî) úprava staví registrované partnerství do situace srovnatelné se situací manželů. ${ }^{40}$

Z hlediska teleologického (zajištění nejbližších pozůstalých), ústavně konformního (čl. 1 a čl. 3 odst. 1 Listiny) i euro-konformního výkladu by podle našeho názoru měla ustanovení o manželství platit obdobně i pro registrované partnerství, resp. by se měl u pojmu ,manžel" uplatnit rozšiřující výklad (teleologická extenze).

\subsection{Přechod náhrad na dědice}

Úmrtí pomáhající osoby v zásadě nemá vliv na existenci jejích práv na náhradu majetkové a nemajetkové újmy, bude se však lišit u těch, která mají výlučně osobní charakter (tradičně jsou za ně považovány právě náhrady za bolest a za ztížení společenského uplatněnî). ${ }^{41}$ Pokud se bude postupovat podle zákoníku práce, stávají se však i tato práva v plné výši předmětem dědického řízení (nap̌r. NS 21 Cdo 936/2010), což je odůvodňováno účelem a specifiky pracovněprávní úpravy. ${ }^{42}$

Pokud se bude postupovat podle občanského zákoníku, má právo na náhradu nemajetkové újmy přecházet pouze $\mathrm{v}$ př́padě, že bylo uznáno nebo uplatněno u orgánu veřejné moci (srov. \1475 odst. 2 a \2009 odst. 2 OZ). Vlivnou částí současné literatury je však popírán výlučný osobní charakter práva na bolestné a na náhradu za ztížení

39 Čl. 3 (3) Tato směrnice se nevztahuje na platby jakéhokoli druhu poskytované státními systémy nebo podobnými, včetně systémů státního sociálního zabezpečení a sociální ochrany.

Pod uvedenou výluku by zřejmě patřilo úmrtné, které má charakter dávky sociálního zabezpečení.

40 Srov. ZPr, část 11 Náhrada majetkové a nemajetkové újmy, hl. III Povinnosti zaměstnavatele k náhradě škody, zvl. \271g a násl. upravující druhy náhrad při úmrtí zaměstnance, kde se kromě manželů přiznávají náhrady také registrovaným partnerům.

41 Blíže DOLEŽAL, Tomáš. Několik poznámek k problematice převoditelnosti práva na náhradu nemajetkové újmy vzniklé v důsledku zásahu do přirozených práv člověka a jeho přechodu na dědice. Časopis zdravotnického práva a bioetiky, Praha: ÚSP AVČR, 2016, roč. 6, č. 1, s. 74-83, zvl. s. 77 a násl.; a PAVELEK, Ondřej. Přechod nároku na bolestné a náhrady za ztížení společenského uplatněni: aktuální otázky. Ad Notam, Praha: Notářská komora ČR, 2017, roč. 23, č. 4, s. 6-9; k přechodu nároku po smrti vojáka blíže VIČAR, Radim, Ondřej HORÁK a Leopold SKORUŠA. Právní aspekty služebního poměru vojáků z povolání - vznik a zánik. In: Národná a medzinárodná bezpečnost 2018: Zborník prispevkov z9. medzinárodnej vedeckej konferencie. Liptovský Mikuláš: Akadémia ozbrojených síl generála M. R. Štefánika, 2018, s. 514-523, zvl. s. 518 a násl. Dostupné z: http://www.aos.sk/struktura/katedry/kbo/NMB2018/ Zbornik_NMB2018.pdf [cit. 15.8.2019].

42 Stejně také DRÁPAL, Ljubomír. Komentář k \328. In: BĚLINA, Miroslav, Ljubomír DRÁPAL a kol. Zákoník práce. Komentár. 2. vyd. Praha: C. H. Beck, 2015, s. 1327; Blíže PICHRT, Jan. Zanikají smrtí zaměstnance pohledávky na náhradu za bolest a za ztížení společenského uplatnění? Bulletin advokacie, Praha: ČAK, 2009, roč. 2, č. 7-8, s. 56-58. 
společenského uplatnění a je dovozováno, že uvedená práva přechází na dědice bez dalšího. ${ }^{43}$ To je také př́stup současné rakouské a německé judikatury. ${ }^{44}$

Z novější judikatury je možné uvést usnesení NS ze dne 27. 4. 2017, sp. zn. 25 Cdo 3556/2016, týkající se přechodných ustanovení ${ }^{45}$, a usnesení NS ze dne 28. 2. 2018, sp. zn. 25 Cdo 293/2018, o děditelnosti práva na náhradu nemajetkové újmy osob blízkých (\ 2959) ${ }^{46}$.

Při pomoci ozbrojeným silám se bude postupovat také podle OZ, $\int 43$ odst. 2 OzbZ totiž v pozn. pod čarou výslovně odkazuje pouze na \116 až \125 VojZ. V tomto ohledu je pomáhající osoba zvýhodněna ve srovnání s vojáky, jejichž nároky na náhradu za bolest a za ztížení společenského uplatnění smrtí zanikají (\$159 odst. 6 VojZ).

$\mathrm{V}$ zákoně o integrovaném záchranném systému je $\mathrm{v}$ př́padě újmy na zdraví výslovně uvedeno, že se peněžní náhrada v případě úmrtí poškozeného poskytne dědicům (srov. \ 30 odst. 3 z. č. 239/2000 Sb., o integrovaném záchranném systému).

\subsection{Srovnání náhrad nemajetkové újmy}

Původně byla poskytována nejvyšší právní ochrana poškozeným při pomoci ozbrojeným silám, nejnižší naopak při pomoci složkám integrovaného záchranného systému. Po rekodifikaci soukromého práva se postavení osob poskytujících součinnost při „běžných“" aktivitách (policie, hasiči) zlepšilo.

Druhy náhrad jsou podle ZP i služebních zákonů obdobné (náhrada za ztrátu na př́imu, bolesti a ztížení společenského uplatnění (ZSU), účelně vynaložených nákladů spojených s léčením, věcné škody, v případě úmrtí: náhrada účelně vynaložených nákladů spojených s léčením a pohřbem, náhrada nákladů na výživu pozůstalých, jednorázové odškodnění pozůstalých), VojZ i ZSP ještě přiznává poškozenému jednorázové mimořádné odškodnění, VojZ pozůstalým poškozeného navíc jednorázové mimořádné odškodnění. Obdobné jsou i prováděcí předpisy (k ZP nařízení vlády č. 276/2015 Sb., k VojZ vyhláška MO č. 346/2015 Sb., k ZSP vyhláška MV č. 277/2015 Sb.), podle ZP se však může soudně domáhat přiměřeného zvýšení odškodnění u náhrady za bolest a ztížení společenského uplatnění a u jednorázového odškodnění pozůstalých (\271s ZP).

43 Srov. FIALA, Roman a Kamila BEEROVÁ. Komentář k $₫ 1475$. In: FIALA, Roman, Ljubomír DRÁPAL a kol. Občanský zákoník IV. Dédické právo 』 1475-1720. Komentár. Praha: C. H. Beck, 2015, s. 5-6.

44 Bliže DOLEŽAL, Tomáš. Několik poznámek k problematice prevoditelnosti práva na náhradu nemajetkové újmy vzniklé v důsledku zásahu do přirozených práv člověka a jeho přechodu na dědice. Časopis zdravotnického práva a bioetiky, Praha: ÚSP AVČR, 2016, roč. 6, č. 1, s. 79.

45 Právní věta: „Zemrél-li v době od 1. 1. 2014 poškozený, jenž utrpěl ájmu na zdraví préd tímto datem, stávají se sou-

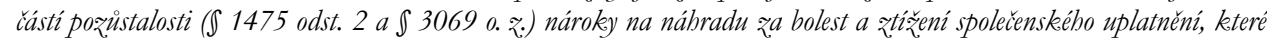
poškožený za svébo života uplatnil u soudu."

46 Právní věta: „Nárok na nábradu za duševni útrapy spojenés usmrcenim osoby blizkeé (I 2959 o. \%.), který byl za života oprávnèné osoby uplatnèn u soudu, tvoř̈ po jeji smrti součást pozuistalosti a prechází na dědice bez obledu na to, zda jim samotným jako osobám bližkým usmrcenému vanikl nárok na jednorázovou nábradu a zda jej uplatnili." 
V občanském právu neexistuje k odškodňování újmy na zdraví prováděcí předpis, stanovení náhrady by mělo být individuální, podpůrně je možné využít Metodiku Nejvyššího soudu. K pozůstalým by se měl řadit také registrovaný partner (v OZ i ZP to je uvedeno výslovně, ve služebních zákonech je sice pamatováno s náhradami pouze na manžela, ale podle euro-konformního výkladu by mělo být analogicky přiznáno také registrovaným partnerům).

Tabulka 1: Přehled náhrad nemajetkové újmy

\begin{tabular}{|c|c|c|c|c|c|}
\hline Právní předpis & $\begin{array}{l}\text { Náhrada } \\
\text { za bolest } \\
\text { a za ztížení } \\
\text { společenského }\end{array}$ & \multicolumn{2}{|c|}{$\begin{array}{l}\text { Jednorázové } \\
\text { (mimořádné) } \\
\text { odškodnění } \\
\text { postiženému }\end{array}$} & \multicolumn{2}{|c|}{$\begin{array}{l}\text { Jednorázové (mimořádné) } \\
\text { odškodnění pozůstalých }\end{array}$} \\
\hline \multirow{2}{*}{$\begin{array}{l}\text { z. č. } 221 / 1999 \text { Sb., } \\
\text { o vojácích } \\
\text { z povolání, resp. } \\
\text { vyhláška MO } \\
\text { č. } 346 / 2015 \mathrm{Sb} \text {. }\end{array}$} & \multirow[t]{2}{*}{$250 \mathrm{Kč} / \mathrm{bod}$} & $\begin{array}{l}\text { 1. a } 2 . \text { st. } \\
\text { invalidity }\end{array}$ & $\begin{array}{l}6 \times \min \\
\operatorname{mzda}\end{array}$ & $\begin{array}{l}\text { manželovi a dítěti } \\
\text { s nárokem } \\
\text { na sirotčí důchod }\end{array}$ & $30 \times$ min. mzda \\
\hline & & $\begin{array}{l}\text { 3. st. } \\
\text { invalidity }\end{array}$ & $\begin{array}{l}24 \times \min \\
\operatorname{mzda}\end{array}$ & $\begin{array}{l}\text { rodiči ve společné } \\
\text { domácnosti }\end{array}$ & $\begin{array}{l}\text { úhrnně } 30 \times \text { min. } \\
\text { mzda }\end{array}$ \\
\hline \multirow{2}{*}{$\begin{array}{l}\text { z. č. } 361 / 2003 \text { Sb., } \\
\text { o služebním } \\
\text { poměru } \\
\text { příslušníků } \\
\text { bezpečnostních } \\
\text { sborů, resp. } \\
\text { vyhláška MV } \\
\text { č. } 277 / 2015 \text { Sb. }\end{array}$} & \multirow[t]{2}{*}{$250 \mathrm{Kč} / \mathrm{bod}$} & \multirow{2}{*}{\multicolumn{2}{|c|}{$\begin{array}{l}\text { základní výše } \\
230000 \text { Kč plus } \\
\text { valorizace }\end{array}$}} & $\begin{array}{l}\text { manželovi } \\
\text { a nezaopatř. dítěti }\end{array}$ & $\begin{array}{l}400000 \text { Kč plus } \\
\text { valorizace }\end{array}$ \\
\hline & & & & $\begin{array}{l}\text { rodiči } \\
\text { v domácnosti }\end{array}$ & $\begin{array}{l}\text { každému } \\
240000 \text { Kč plus } \\
\text { valorizace }\end{array}$ \\
\hline \multirow{2}{*}{$\begin{array}{l}\text { z. č. } 262 / 2006 \mathrm{Sb} \text {., } \\
\text { zákoník práce, } \\
\text { resp. nař. vl. } \\
\text { č. } 276 / 2015 \mathrm{Sb} \text {. }\end{array}$} & \multirow[t]{2}{*}{$250 \mathrm{Kč} / \mathrm{bod}$} & \multirow{2}{*}{\multicolumn{2}{|c|}{ neposkytuje se }} & $\begin{array}{l}\text { manželovi, } \\
\text { partnerovi } \\
\text { a nezaopatř. dítěti }\end{array}$ & $\begin{array}{l}\text { každému min. } \\
240000 \mathrm{Kč}\end{array}$ \\
\hline & & & & $\begin{array}{l}\text { rodičům (rodiči) } \\
\text { v domácnosti }\end{array}$ & $\begin{array}{l}\text { úhrnně min. } \\
240000 \mathrm{Kč}\end{array}$ \\
\hline \multirow{2}{*}{$\begin{array}{l}\text { z. č. } 89 / 2012 \text { Sb., } \\
\text { občanský zákoník, } \\
\text { resp. Metodika } \\
\text { Nejvyššího soudu }\end{array}$} & \multicolumn{3}{|c|}{$\begin{array}{l}\text { bolestné: } 1 \text { \% prům. hrub. měs. nom. } \\
\text { mzdy v nár. hosp. za před. kal. rok / } \\
\text { bod (v roce } 2019318,85 \text { Kč) }\end{array}$} & \multirow{2}{*}{\multicolumn{2}{|c|}{$\begin{array}{l}\text { odškodnění při usmrcení osoby } \\
\text { blízké: základem } 20 \text {-tinásobek } \\
\text { prům. hrub. měs. nom. mzdy } \\
\text { v nár. hosp. za před. kal. rok } \\
\text { (podle rozsudku NS sp. zn. } 25 \text { Cdo } \\
\text { 894/2018) }\end{array}$}} \\
\hline & \multicolumn{3}{|c|}{$\begin{array}{l}\text { ZSU: až 400-násobek prům. hrub. } \\
\text { měs. nom. mzdy v nár. hosp. za před. } \\
\text { kal. rok (v roce } 201912754000 \text { Kč) }\end{array}$} & & \\
\hline
\end{tabular}

Zdroj: autoři 


\section{3 Úvaha de lege ferenda}

Platná právní úprava (osmnáct zákonů z let 1985 až 2014) řeší problematiku náhrady újmy legislativně-technicky různě. To nečiní v zásadě problém u majetkové újmy (škody), protože se bude postupovat prímo nebo subsidiárně podle občanskoprávní úpravy. $\mathrm{V}$ př́ipadě náhrady nemajetkové újmy (na zdraví nebo při usmrcenî) by však byla vhodná unifikace jednotlivých úprav, a to podle zákoníku práce, resp. pracovněprávních předpisů (doplněných o jednorázové mimořádné odškodněnî). Na podporu našeho názoru můžeme uvést minimálně tři důvody (principiální, kvantitativní a praktický): 1) neměly by se rozlišovat následky pomoci podle jednotlivých veřejných sborů (proč by se např. měla jinak odškodňovat pomoc policistům x vojenským policistům, nebo pomoc hasičům x záchranářům, jak je tomu dnes), 2) nejvíce zákonů odkazuje na pracovněprávní úpravu, 3) předcházelo by se soudním sporům - prováděcí nařízení vlády poskytuje pevný základ pro odškodňování (zohlednění zásady legality při působení veřejných sborů, resp. při uplatňování veřejné moci), je však možné se také domáhat zvýšení náhrad soudem (zohlednění specifik každého případu i přirozenoprávních tendencí v souvislosti s rekodifikací OZ).

$\mathrm{V}$ neposlední řadě můžeme pro unifikaci uvést ještě historický důvod - už zákonem č. 267/2006 Sb., o změně zákonů souvisejících s přijetím zákona o úrazovém pojištění zaměstnanců, měla být úprava pomoci veřejným sborům sjednocena, ale nakonec byl tento doprovodný předpis stejně jako zákon o úrazovém pojištění ještě před svou (opakovaně prodlužovanou) účinností zrušen (zákonem č. 205/2015 Sb., kterým se mění zákon č. 262/2006 Sb., zákoník práce, ve znění pozdějších předpisů, zrušuje zákon č. 266/2006 Sb., o úrazovém pojištění zaměstnanců, a zrušují nebo mění některé další zákony).

\section{Závěr}

Odpovědnost za újmu osobě, která poskytla veřejné moci (úředním osobám) součinnost, stojí na pomezi odpovědnosti vưči „vlastním“ (osobám ve služebním poměru) a vůči „cizím“ (třetím osobám). Představuje specifický prrípad odpovědnosti státu ve veřejné sféře, jedná se o objektivní odpovědnost (za výsledek).

U náhrady majetkové újmy (škody) se má v zásadě postupovat podle občanského zákoníku: 1) ve čtyřech prrípadech to je uvedeno výslovně (při pomoci jednotkám požární ochrany, ozbrojeným silám, složkám IZS a rybářské stráži), ve čtyřech to je dovozováno výkladem (při pomoci BIS, orgánům krizového řízení, výjezdové skupině a služebnímu úřadu), v devíti př́padech je úprava samostatná, ale $\mathrm{OZ}$ se použije subsidiárně (při pomoci obecní policii, Vězeňské službě, strážím přírody, lesní a myslivecké, Policii ČR, GIBS a Celní správě). 
U náhrady nemajetkové újmy (na zdraví nebo smrti) se má postupovat: 1) při pomoci ozbrojeným silám podle zákona o vojácích z povolání, 2) v devíti prípadech podle zákoníku práce (při pomoci jednotce požární ochrany, Vězeňské službě, strážím prrírody, lesní, myslivecké a rybářské, státu při zajišt'ování životně důležitých funkcí, složkám integrovaného záchranného systému a orgánům krizového řízení, a 3) v osmi prípadech podle občanského zákoníku (u pomoci obecní policii, Policii ČR, GIBS a Celní správě to je stanoveno výslovně, při pomoci BIS, výjezdové skupině, zaměstnanci finanční správy a státnímu zaměstnanci to je dovozováno literaturou). Pro lepší názornost uvádíme přehled náhrad za újmu osobě poskytující pomoc v tabulce $2 .{ }^{47}$

De lege ferenda by bylo vhodné jednotlivé úpravy sjednotit, a to nejlépe formou odkazu př́mo v textu zákonů na občanský zákoník v případě majetkové újmy a na zákoník práce (resp. pracovněprávní předpisy) v prrípadě nemajetkové újmy. Vyřešilo by to jak nedůvodné rozdíly úpravy náhrad újmy při pomoci jednotlivým veřejným sborům, tak dalo pevné východisko pro poškozené osoby i veřejné sbory.

Tabulka 2: Přehled náhrad za újmu osobě poskytující pomoc

\begin{tabular}{|c|c|c|c|c|}
\hline \multirow[b]{2}{*}{ Pomoc pro } & \multirow[b]{2}{*}{ Právní předpis } & \multicolumn{2}{|c|}{ Náhrada } & \multirow{2}{*}{$\begin{array}{l}\text { Orgán } \\
\text { poskytující } \\
\text { náhradu }\end{array}$} \\
\hline & & $\begin{array}{c}\text { škody } \\
\text { na věcech }\end{array}$ & $\begin{array}{l}\text { újmy } \\
\text { na zdraví }\end{array}$ & \\
\hline $\begin{array}{l}\text { Hasičský záchranný } \\
\text { sbor, resp. jednotky } \\
\text { požární ochrany }\end{array}$ & $\begin{array}{l}\int 80-84 \text { z. č. } 133 / 1985 \text { Sb., } \\
\text { o požární ochraně }\end{array}$ & $\mathrm{OZ}$ & ZP & $\begin{array}{l}\text { HZS kraje, } \\
\text { v jehož územním } \\
\text { obvodu k újmě } \\
\text { došlo }\end{array}$ \\
\hline Obecní policie & $\begin{array}{l}\text { S } 24 \text { z. č. } 553 / 1991 \text { Sb., } \\
\text { o obecní policii }\end{array}$ & $\begin{array}{l}\text { vlastní úpr., } \\
\text { subsidiárně OZ }\end{array}$ & OZ & Obec \\
\hline Vězeňská služba & $\begin{array}{l}\text { S } 23 \text { z. č. 555/1992 Sb., } \\
\text { o Vězeňské službě } \\
\text { a justiční stráži ČR }\end{array}$ & $\begin{array}{l}\text { vlastní úpr., } \\
\text { subsidiárně OZ }\end{array}$ & $\mathrm{ZP}$ & $\begin{array}{l}\text { Ministerstvo } \\
\text { spravedlnosti }\end{array}$ \\
\hline $\begin{array}{l}\text { Bezpečnostní } \\
\text { informační služba }\end{array}$ & $\begin{array}{l}\text { S } 17 \text { z. č. } 154 / 1994 \text { Sb., } \\
\text { o Bezpečnostní informační } \\
\text { službě }\end{array}$ & OZ (dovo & zeno) & BIS \\
\hline $\begin{array}{l}\text { ozbrojené } \\
\text { síly, Vojenská } \\
\text { policie, Vojenské } \\
\text { zpravodajství }\end{array}$ & $\begin{array}{l}\int 43 \text { z. č. } 219 / 1999 \text { Sb., } \\
\text { o ozbrojených silách ČR }\end{array}$ & $\mathrm{OZ}$ & Vojz & $\begin{array}{l}\text { Ministerstvo } \\
\text { obrany }\end{array}$ \\
\hline
\end{tabular}

47 Zákony jsou ve znění pozdějších předpisů, u většiny již došlo u náhrady škody k novelizacím, zejména z. č. 303/2013 Sb., kterým se mění některé zákony v souvislosti s přijetím rekodifikace soukromého práva. Problém přineslo zejména zrušení zákona č. 267/2006 Sb., o změně zákonů souvisejících s přijetím zákona o úrazovém pojištění zaměstnanců, ještě před jeho účinností, což některé informační systémy (Beck-online) nedostatečně zohlednily (srov. \ 30 z. č. 239/2000 Sb. a \36 z. č. 240/2000 Sb.). 


\begin{tabular}{|c|c|c|c|c|}
\hline \multirow{2}{*}{\begin{tabular}{|l|} 
stát \\
ozbrojené síly
\end{tabular}} & \multirow{2}{*}{$\begin{array}{l}\int 59-63 \text { z. č. } 222 / 1999 \mathrm{Sb} . \\
\text { o zajišt'ování obrany ČR }\end{array}$} & \multirow{2}{*}{$\begin{array}{c}\text { vlastní úpr., } \\
\text { subsidiárně OZ }\end{array}$} & \multirow{2}{*}{$\begin{array}{c}\text { ZP } \\
\text { VojZ }\end{array}$} & \multirow{2}{*}{$\begin{array}{l}\text { obecní úřad obce } \\
\text { s rozšířenou } \\
\text { působností } \\
\text { pŕślušný } \\
\text { podle místa } \\
\text { trvalého pobytu } \\
\text { poškozeného }\end{array}$} \\
\hline & & & & \\
\hline stráž prírody & $\begin{array}{l}\int 81 b \text { z. č. } 114 / 1992 \text { Sb., } \\
\text { o ochraně př́rody a krajiny }\end{array}$ & $\begin{array}{l}\text { vlastní úpr., } \\
\text { subsidiárně OZ }\end{array}$ & $\mathrm{ZP}$ & $\begin{array}{l}\text { orgán, který } \\
\text { ji ustanovil }\end{array}$ \\
\hline lesní stráž & $\begin{array}{l}\text { @ 39a z. č. 289/1995 Sb., } \\
\text { lesní zákon }\end{array}$ & $\begin{array}{l}\text { vlastní úpr., } \\
\text { subsidiárně OZ }\end{array}$ & $\mathrm{ZP}$ & $\begin{array}{l}\text { orgán státní } \\
\text { správy lesů, který } \\
\text { ji ustanovil }\end{array}$ \\
\hline myslivecká stráž & $\begin{array}{l}\int 16 \text { z. č. } 449 / 2001 \mathrm{Sb} \text {, } \\
\text { o myslivosti }\end{array}$ & $\begin{array}{l}\text { vlastní úpr., } \\
\text { subsidiárně OZ }\end{array}$ & $\mathrm{ZP}$ & $\begin{array}{l}\text { orgán státní } \\
\text { správy myslivosti, } \\
\text { který ji ustanovil }\end{array}$ \\
\hline rybářská stráž & $\begin{array}{l}\int 18 \text { z. č. } 99 / 2004 \text { Sb., } \\
\text { o rybářství }\end{array}$ & OZ & $\mathrm{ZP}$ & $\begin{array}{l}\text { obecní úř́ad obce } \\
\text { s rozšířenou } \\
\text { působností, který } \\
\text { ji ustanovil }\end{array}$ \\
\hline složky IZS & $\begin{array}{l}\text { S } 30 \text { z. č. } 239 / 2000 \text { Sb., } \\
\text { o integrovaném } \\
\text { záchranném systému }\end{array}$ & OZ & $\mathrm{ZP}$ & $\begin{array}{l}\text { krajský úřad, } \\
\text { v jehož správním } \\
\text { obvodu újma } \\
\text { vznikla }\end{array}$ \\
\hline $\begin{array}{l}\text { orgány krizového } \\
\text { řízení }\end{array}$ & $\begin{array}{l}\int 36 \text { z. č. } 240 / 2000 \text { Sb., } \\
\text { o krizovém řízení }\end{array}$ & OZ (dovozeno) & $\mathrm{ZP}$ & $\begin{array}{l}\text { orgán krizového } \\
\text { rrízení, který } \\
\text { nařídil krizové } \\
\text { opatření }\end{array}$ \\
\hline Policie ČR & $\begin{array}{l}\text { S } 95-96 \text { z. č. } 273 / 2008 \text { Sb., } \\
\text { o Policii ČR }\end{array}$ & $\begin{array}{l}\text { vlastní úpr., } \\
\text { subsidiárně OZ }\end{array}$ & OZ & $\begin{array}{l}\text { Ministerstvo } \\
\text { vnitra }\end{array}$ \\
\hline $\begin{array}{l}\text { Generální inspekce } \\
\text { bezpečnostních } \\
\text { sborů }\end{array}$ & $\begin{array}{l}\text { \ } 55 \text { z. č. zákon } \\
\text { č. } 341 / 2011 \text { Sb., } \\
\text { o Generální inspekci } \\
\text { bezpečnostních sborů }\end{array}$ & $\begin{array}{r}\text { použijí se ob } \\
\text { 『95 a } 96 \text { zákon } \\
\text { ČR }\end{array}$ & $\begin{array}{l}\text { bdobně } \\
\text { na o Policii }\end{array}$ & GIBS \\
\hline $\begin{array}{l}\text { zdravotnická } \\
\text { záchranná služba, } \\
\text { resp. členové } \\
\text { výjezdové skupiny }\end{array}$ & $\begin{array}{l}\text { \ } 18 \text { odst. } 4 \\
\text { z. č. } 374 / 2011 \text { Sb., } \\
\text { o zdravotnické záchranné } \\
\text { službě }\end{array}$ & OZ (dovo & zeno) & $\begin{array}{l}\text { poskytovatel } \\
\text { zdravotnické } \\
\text { záchranné služby }\end{array}$ \\
\hline $\begin{array}{l}\text { zaměstnanec } \\
\text { finanční správy }\end{array}$ & $\begin{array}{l}\int 17 \text { z. č. } 456 / 2011 \text { Sb. } \\
\text { o Finanční správě České } \\
\text { republiky }\end{array}$ & $\begin{array}{l}\text { vlastní úpr., } \\
\text { subsidiárně OZ }\end{array}$ & $\begin{array}{c}\mathrm{OZ} \\
(\text { dovozeno) }\end{array}$ & $\begin{array}{l}\text { Generální } \\
\text { finanční } \\
\text { reditelství }\end{array}$ \\
\hline Celní správa & $\begin{array}{l}\text { \ } 51 \text { a } 52 \text { z. č. } 17 / 2012 \text { Sb., } \\
\text { o Celní správě ČR }\end{array}$ & $\begin{array}{l}\text { vlastní úpr., } \\
\text { subsidiárně OZ }\end{array}$ & $\mathrm{OZ}$ & $\begin{array}{l}\text { Generální } \\
\text { ředitelství cel }\end{array}$ \\
\hline státní zaměstnanec & $\begin{array}{l}\text { S } 125 \text { z. č. } 234 / 2014 \text { Sb., } \\
\text { o státní službě }\end{array}$ & OZ (dovo & zeno) & služební úřad \\
\hline
\end{tabular}

Zdroj: autoři 